\title{
Survey on Ethnoveterinary Practices around Junagadh, Gujarat, India
}

\author{
P. R. BHATT ${ }^{*}$, KAJAL B. PANDYA, U. D. PATEL, H. B. PATEL AND C. M. MODI
}

Department of Veterinary Pharmacology and Toxicology, College of Veterinary Science and Animal Husbandry, Junagadh Agricultural University, Junagadh-362 001, India

Bhatt et al.: Traditional Veterinary Practices in Junagadh Region 
This study was conducted between January to July 2015 in Junagadh and surrounding villages to document the use of medicinal plants for veterinary practices by people living in this area. A total 121 farmers, cowshed owners or livestock owners were contacted personally in the survey with a semi-structured questionnaire. Out of 121, 82 male informants of age 40 to 70 years have responded well and were included in this study. Sixty-seven medicinal plants from 40 different families have been reported to be effective in $\mathbf{1 3}$ different animal ailments. A total of 13 medicinal plants were cited 47 times for gastrointestinal problems, which were the highest. Leaves were used prominently $(27.59 \%)$ whereas, epicarp was the least used $(0.86 \%)$. Large number of medicinal plants reported were from the Fabaceae family $(15.38 \%)$. Junagadh area is important due to a large plant biodiversity.

\section{Key words: Ethnopharmacology, veterinary practices, traditional knowledge, Saurashtra, folklore, Gujarat}

Ethnoveterinary practices include the use of local medicinal plants to prevent, cure or treat various ailments in animals. It can be considered as traditional knowledge, which is used for the well-being of animals ${ }^{[1]}$. Ethnoveterinary practices are known in India since the ancient Vedic period. Cattle husbandry was well developed during the Rigvedic period (15001000 BC) and the cow. 'Kamdhenu' was adored and considered as the best wealth of mankind. Atharvaveda provided interesting information about ailments and herbal medicinal cures for diseases of humans, cows and horses ${ }^{[2]}$. Medicinal plants like Arjuna (Terminalia arjuna), Indrajava (Holarrhena antidysenterica), Kadamba (Anthocephalus cadamba), Neem (Azadirachta indica), Asana (Pterocarpum marsupium) and Ashoka (Saraca asoca) were commonly employed by Vedic Aryans to cure ailments of animals and men ${ }^{[3]}$. The oldest ancient treatise on veterinary Ayurveda is Asvayurvedasiddhanta (complete Ayurveda of horse). The text entitled Hastyayurveda (the Ayurveda of elephant) ascribed to Dhanvantari, the father of Ayurveda $^{[4]}$.

Gujarat state in India is a rich source of flora. As per Gujarat Biodiversity Board, 2198 angiosperm species are found in Gujarat, which is $12.56 \%$ of total species found in India. Junagadh is located near to the Sasan Gir forest, which is the only Lion sanctuary in Asia. The average rainfall in this region is about 400 to $1000 \mathrm{~mm}$. The coldest and warmest months are December and April, May, respectively ${ }^{[5]}$. Ethnoveterinary knowledge existed in Junagadh region of Gujarat state, due to various communities like Charan, Maldharies, Rabaris, Kunbies and Maher. These communities are nurturing various animals like cows, buffalos, sheep and goats in this region since long ${ }^{[6]}$.

*Address for correspondence E-mail: punitbhatt85@gmail.com

January-February 2019

Indian Journal of Pharmaceutical Sciences
Traditional knowledge is being forgotten these days due to the advent of latest technologies, hence some researchers are attempting to document this fragile knowledge as written reports ${ }^{[7]}$. Dependence of poor people on medicinal plant-based treatments may be due to unavailability of hospitals in the nearby area as well as allopathic drugs ${ }^{[8]}$. Due to easy availability and low cost of medicinal plants, the livestock owners of the remote areas use them as a first aid for their animals ${ }^{[9]}$. Documentation of traditional ethnoveterinary knowledge is a requirement due to increasing demand for herbal drugs in the veterinary field along with some known side-effects of allopathic products. Recognization of ethnoveterinary practices in this region and their documentation is necessary for creating new herbal-based treatments. Thus, the present study was carried out to gather traditional knowledge from the animal keepers of different age and education status. This documentation may help to create awareness of the importance of veterinary therapy with medicinal plants.

Three tehsils of Junagadh, Mendarda and Vanthali of Junagadh district were selected primarily for the study. Four villages from each tehsil were randomly selected for this study, which were Plaswa, Bandhala, Majewadi, Bilkha from Junagadh; Barvala, Rajeshar, Araniyala, Aalidhra from Mendarda; and Gadoi, Vadla, Navagam, Nagadiya from Vanthali.

Study participants were selected randomly from each village included in the study area. Selection criteria

This is an open access article distributed under the terms of the Creative Commons Attribution-NonCommercial-ShareAlike 3.0 License, which allows others to remix, tweak, and build upon the work non-commercially, as long as the author is credited and the new creations are licensed under the identical terms

Accepted 20 November 2018 Revised 20 April 2018 Received 05 May 2017 Indian J Pharm Sci 2019;81(1):161-167 
for the participants included, either he should maintain animals at their home or on the farm or they should be engaged in animal keeping activities since $5 \mathrm{y}$ or more. Minimum 10 participants from each village were contacted randomly. All participants were contacted either at their farm or at home. There were no female participants in this study due to the patriarchal nature in these villages hence only male participants were included. Some cowshed owners were also contacted for this survey.

A semi-structured questionnaire was prepared in the local Gujarati language, which contained more than 8 questions that included personal details along with contact numbers (if any), occupation, ailments of animals and medicinal plants used in particular ailments, type of application of plants and part of the plant. The plant species cited by the informant were determined from, flora of Gujarat ${ }^{[10]}$, and other traditional books written in the Gujarati language ${ }^{[11,12]}$.

Plants consumed in the ethnoveterinary practice in the Junagadh and surrounding area were investigated in this study. Total 67 plant species from 40 different families were documented for different purposes in the area (Table 1). Face-to-face interviews were conducted with the participants with a semi-structured questionnaire, which contained basic questions related to the aim of this study. Number of participants were highest in Mendarda (34.15\%) tehsil followed by Junagadh (32.93\%) and Vanthali (32.93\%) as shown in fig. 1A. All 82 participants interviewed in various tehsils were males in the age range of 40 to $70 \mathrm{y}$ or more (fig. 1B). Participants in the age range of 40 to 50 y demonstrated more ethnoveterinary knowledge as compared to other groups. This shows that the

\section{TABLE 1: MEDICINAL PLANTS USED IN ETHNOVETERINARY PRACTICE IN JUNAGADH REGION OF} GUJARAT, INDIA

\begin{tabular}{|c|c|c|}
\hline Scientific name with family & $\begin{array}{l}\text { Vernacular } \\
\text { name }\end{array}$ & Medicinal use of different parts of plants \\
\hline Abrus precatorius L. (Fabaceae) & Chanothi & Crushed seed given with jaggery in retention of the placenta \\
\hline Achyranthes aspera L. (Amaranthaceae) & Aghedo & Juice of the seed in light warm water given in gastric disturbance \\
\hline Adansonia digitata L. (Bombacaceae) & $\begin{array}{l}\text { Gorakh } \\
\text { ambli }\end{array}$ & A paste of fruits is applied locally to wound and orally for enteritis \\
\hline Adhatoda vasica Nees. (Acanthaceae) & Ardusi & Leaves are used in mild to moderate cough \\
\hline Aegle marmelos (L.) Corrêa. (Rutaceae) & Billi & Crushed fruits given orally for diarrhoea \\
\hline Allium cepa L. (Liliaceae) & Dungli & Fresh bulbs given for retention of the placenta \\
\hline Aloe barbadensis Mill. (Liliaceae) & Kuvarpathu & Fresh leaf gel for burns, itching and wounds \\
\hline $\begin{array}{l}\text { Anacyclus pyrethrum (L.) Lag. } \\
\text { (Compositae) }\end{array}$ & Akkal karo & $\begin{array}{l}\text { Crushed root decoction given up to } 250 \mathrm{ml} \text { for retention of the } \\
\text { placenta }\end{array}$ \\
\hline $\begin{array}{l}\text { Anethum sowa Roxb. ex Flem. } \\
\text { (Umbelliferae) }\end{array}$ & Suva & Fresh cold decoction of seed given in stomach problems \\
\hline Annona squamosa L. (Annonaceae) & Sitaphali & Fresh leaf paste with sugar applied locally for wound and maggots \\
\hline $\begin{array}{l}\text { Aristolochia bracteolata Lam. } \\
\text { (Aristolochiaceae) }\end{array}$ & Kidaamari & $\begin{array}{c}\text { Fresh paste applied for the treatment of maggots and parasites on } \\
\text { the skin }\end{array}$ \\
\hline $\begin{array}{l}\text { Asparagus racemosus willd. } \\
\text { (Asparagaceae) }\end{array}$ & Satavari & Root is used as a galactagogue in cow and buffalo \\
\hline Azadirachta indica A. Juss. (Meliaceae) & Kadvo Limdo & $\begin{array}{c}\text { Fresh cold decoction of leaf and stem bark is applied to itching and } \\
\text { skin infections }\end{array}$ \\
\hline Bauhinia variegata L. (Caesalpiniaceae) & Kachnar & Powdered bark applied externally for wounds \\
\hline $\begin{array}{l}\text { Bryophyllum pinnatum (Lam.) Oken } \\
\text { (Crassulaceae) }\end{array}$ & Paanfuti & $\begin{array}{l}\text { Leaf paste along with Aegle marmelos fruit pulp given for chronic } \\
\text { stomach problems and mild urinary tract problems in cattle }\end{array}$ \\
\hline $\begin{array}{l}\text { Butea monosperma (Lam.) Taub. } \\
\text { (Fabaceae) }\end{array}$ & Khakharo & Powder of bark applied to the wound for quick healing. \\
\hline $\begin{array}{l}\text { Calotropis procera (Aiton) Dryand. } \\
\text { (Asclepiadaceae) }\end{array}$ & Aakado & $\begin{array}{c}\text { Leaf paste or entire fresh leaf applied along with Cassia auriculata } \\
\text { leaf paste for chronic joint inflammation }\end{array}$ \\
\hline Carissa carandas L. (Apocynaceae) & Karmada & $\begin{array}{l}\text { Juice of the fresh plant used for infected wounds that refuse to } \\
\text { heal }\end{array}$ \\
\hline Cassia fistula L. (Caesalpiniaceae) & Garmalo & Seeds given along with jaggery for stomach problems \\
\hline Cassia tora L. (Calsalpiniaceae) & diyo & $\begin{array}{l}\text { Fresh paste of seed and root applied locally for ringworm and } \\
\text { fungal infection }\end{array}$ \\
\hline $\begin{array}{l}\text { Centratherum anthelminticum (L.) } \\
\text { Gamble (Asteraceae) }\end{array}$ & Kalijiri & maggot $v$ \\
\hline
\end{tabular}


www.ijpsonline.com

\author{
Citrus medica L. (Rutaceae) \\ Clerodendrum phlomidis L. f. \\ (Verbenaceae) \\ Coccinia grandis (L.) Voigt \\ (Cucurbitaceae) \\ Cocos nucifera L. (Arecaceae) \\ Cordia dichotoma G. Forst. \\ (Boraginaceae)
}

Curcuma amada Roxb. (Zingiberaceae)

Curcuma longa L. (Zingiberaceae)

Cymbopogon citratus (DC.) Stapf. (Poaceae)

Datura metel L. (Solanaceae)

Derris indica (Lamk.) Bennet.

(Fabaceae)

Eclipta alba (L.) Hassk. (Compositae)

Elephantopus scaber L. (Compositae)

Enicostemma littorale auct. Non-Bl

(Gentianaceae)

Euphorbia nivulia Buch.-Ham.

Euphorbiaceae

Ferula foetida (Umbelliferae)

Ficus bengalensis L. (Moraceae)

Ficus racemosa L. Syn. Ficus glomerata

Roxb. (Moraceae)

Ficus religiosa L. (Moraceae)

Glycyrrhiza glabra L. (Fabaceae)

Lepidium sativum L. (Curciferace)

Leptadenia reticulata (Retz.) Wight \&

Arn. (Asclepiadaceae)

Mangifera indica L. (Anacardiaceae)

Moringa oleifera Lam. (Moringaceae)

Murraya koenigii (L.) Spreng. (Rutaceae)

Ocimum sanctum L. (Labiatae)

Pandanus tectorius Soland.ex

Parkinson (Pandanaceae)

Peltophorum pterocarpum

(DC) K. Heyne. (Caesalpiniaceae)

Piper nigrum L. (Piperaceae)

Prosopis juliflora (Sw.) DC.

(Mimosaceae)

Psoralea corylifolia L. (Fabaceae)

Pueraria tuberosa (Willd.) DC

(Fabaceae)

Punica granatum L. (Punicaceae)

Sapota achras Mill. (Sapotaceae)

Semecarpus anacardium L.

(Anacardiaceae)

Solanum melongena L. (Solanaceae)

Solanum xanthocarpum Schrad. \& H.

Wendl. (Solanaceae)

Syzygium cuminii Merr. (Myrtaceae)
Bijoroo

Fresh decoction of the plant given as a supplement to cattle

Arni

Fresh paste is applied to worm and other foot diseases

Tindora

Naliyeri

Gunda

Fruit is an antidiabetic

Cattle exposed to a fog of dry leaves for chronic cough

Powder of bark used externally for wound healing. Fresh juice given for intestinal worms

Powdered rhizome paste applied for foot joint inflammation, bone

Amba haldar fractures. Thick syrupy solution in water given internally to oxen in hyperventilation

Haldar

Lemon Grass

Dhaturo

Karanj

Bhangro

Gojihva

Mamejvo

Dandaliyo thor

Hing

Vad

Umbaro

Pipalo

Jethi Madh

Sheliyo

Dodi

Ambo

Saragvo

Mitho limdo

Tulsi

Kevado

Pilo

gulmohar

Kala mari

Gando

bawal

Baauchi

Fagiya ni

ganth

Dadam

Chikoo

Bhilama

Ringna

Bhoi ringni

Kala Jambu

Warm paste applied locally for inflammation, antiseptic

Given with fodder for anorexia in cattle

Leaf paste applied in painful injuries of ankle bone

5 to $10 \mathrm{~g}$ seed are crushed in water and apply for itching and pruritus

Leaf paste is applied to wound along with other herbs

Commonly used for wound healing in cattle

Stomach problems and treatment of intestinal worms

Fog of dried stems for the treatment of cough. Fresh paste of stem applied locally for inflammation

Given in flatulence

Bark paste applied in fractures along with other herbs

Fruits given with fodder for liquidy dung due to stomach

problems. Bark paste externally used for wound healing and minor haemorrhages

Juice of leaf and bark given for vaginal prolapse

Root powder given with water for the treatment of cough

Seeds given as a supplement during pregnancy

Fruit paste applied to various skin problems

Ash of bark given for cough and respiratory problems

To increase milk production in cow and buffalo

Leaf given with fodder during diarrhoea and related problems

Used as antiseptic, antibacterial

Fresh water decoction of leaf is used to all types of wounds

Bark decoction given in diarrhoea. Pods used externally for mild to moderate inflammation

Fruit given with fodder for indigestion

Leaf and fruit paste applied locally for infections in cattle

Seed paste applied to itching and other related skin problems

Chopped tubers given orally to increase milk production. Tuber decoction suggested for urinary problems

Fresh decoction of fruit epicarp is given orally for diarrhoea and bloat

Unripe fruits given in diarrhoea

Fruits given to treat retention of the placenta

Fruits given with fodder for retention of the placenta

Fruit is used in treatment of a cough and respiratory diseases

Fruit and leaves are antidiabetic. Leaf paste applied as antibacterial on wound 
www.ijpsonline.com

Tagetes erecta L. (Compositae)

Tamarindus indica L. (Caesalpiniaceae)

Tecomella undulata (Sm.) Seem. (Bignoniaceae)

Terminalia arjuna (Roxb. ex DC.) Wight \& Arn. (Combretaceae)

Thespesia populnea (L.) Soland. ex

Correa (Malvaceae)

Trachyspermum ammi (L.) Sprague

(Umbelliferae)

Tridax procumbens (L.) L.

Vitex negundo L. (Verbenaceae)

Zingiber officinale Roscoe

(Zingiberaceae)
Galgota

Ambali

Ragat

rohido

Arjun

Paras piplo

Ajmo

Gha buri

Nagod

Aadu
Fresh paste of flower petals applied to the wound

Treatment of stomach pain due to ingestion of castor seed

Dilute decoction to wash infected eyes. Bark paste applied along with other herbs for bone fracture. orally given to treat intestinal worms

Bark juice is given to hyperventilated oxen in the field

Bark paste applied for skin diseases and itchy skin

Leaf juice given in common stomach problems

Fresh juice applied to wounds

Leaf paste applied externally for mild to moderate inflammation

Crushed rhizomes along with jaggery given to cattle in bloat and indigestion

*All botanical names of medicinal plants verified on www.plantlist.org

knowledge of ethnoveterinary practice is in the hands of middle aged people, which might have been inherited. Participants who had education, from 5 to 9 standards were found to possess good ethnoveterinary knowledge in all three tehsils. The highest number of participants with education up to $10^{\text {th }}$ standard and above were found in the Mendarda tehsil (fig. 1C). Even with a low level of primary or secondary school education, participants demonstrated good traditional knowledge, which suggested ethnoveterinary information is being inherited.

GIT problems, wound healing, skin-related disorders, respiratory problems and inflammatory conditions were listed more compared to other diseases. Out of the 67 medicinal plants, 22.03 and $13.56 \%$ were used for treating bloating, diarrhoea and wound healing action, whereas about $10.17 \%$ plants were used for skin problems, respiratory problems and inflammationrelated problems (fig. 2A). Apart from these, for treating retention of the placenta, parasitic infections, bone fracture, milk let down problem, vaginal and urinary tract problems, a number of plants alone and/or in combinations were commonly used. Leaves (27.59 \%) and fruits $(18.97 \%)$ were used predominantly, while epicarp, exudate and rhizomes were used sparingly (4.31\%; fig. 2B).

Some farmers have reported the use of fresh juice of Tridax procumbent in large ruminant injuries. This plant was reported to exhibit antiseptic and antihemorrhagic activity ${ }^{[13,14]}$. These activities of this plant might be due to the presence of steroids and triterpenes ${ }^{[15]}$. Another report from one of the farmers indicated use of fresh decoction of Prosopis juliflora leaves when an animal suffered from infectious diseases. Phytochemical

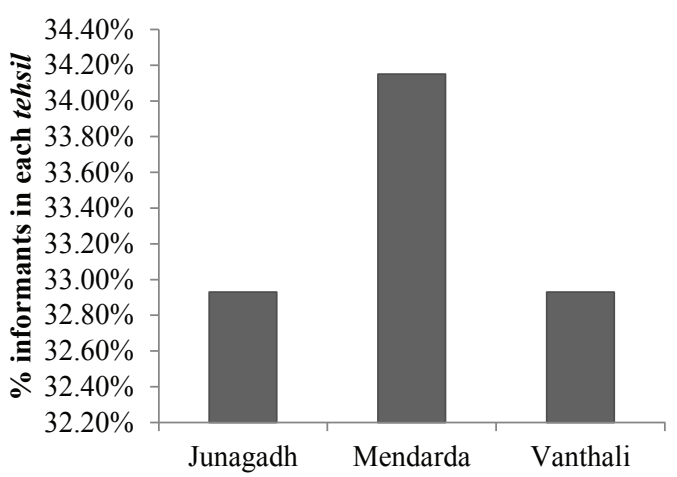

A.
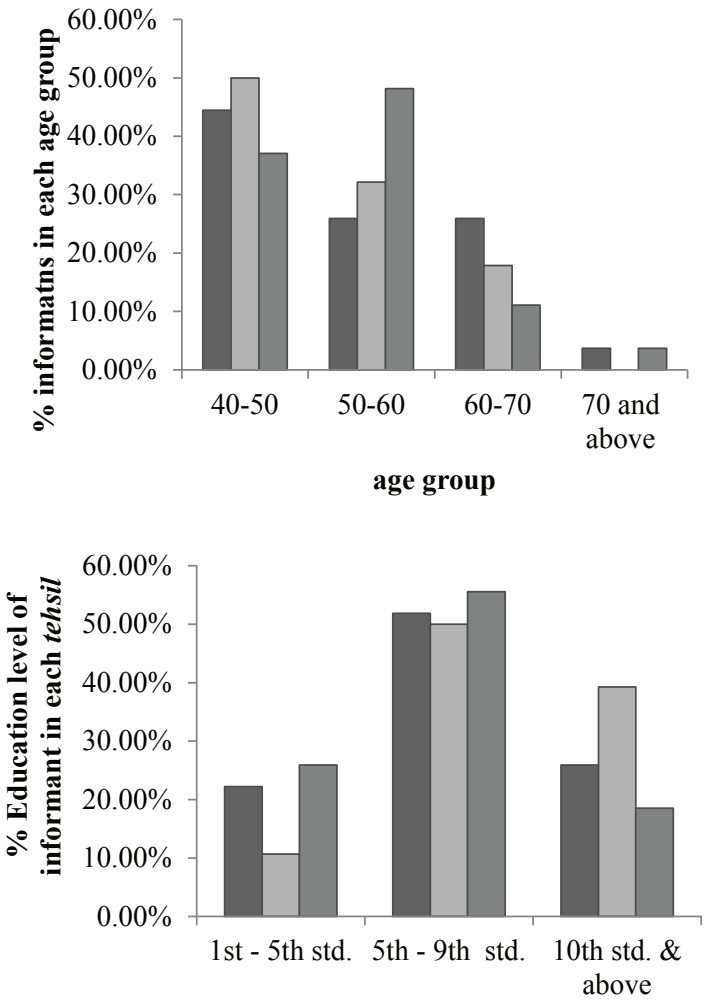

Fig. 1: Statistical details of the participants

(A) Percent participants in each district (B) percent distribution of participants age-wise (C) education level of participants in the study area. $\square$ Junagadh, $\square$ Mendarda, $₫$ Vanthali 

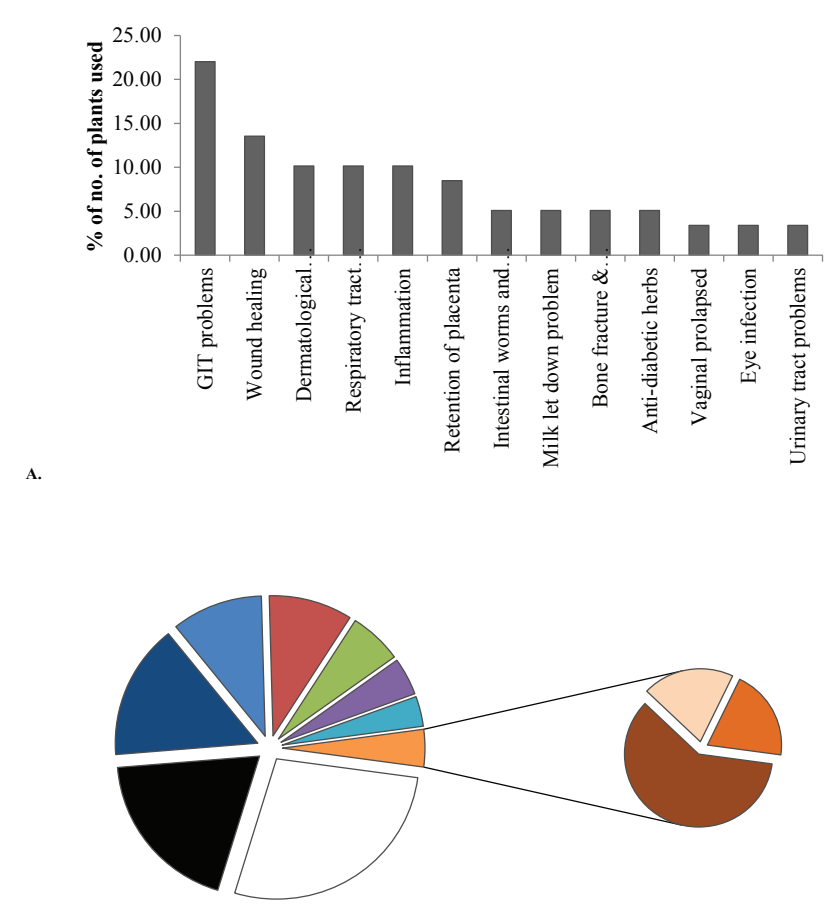

Fig. 2: Distribution of ailments and plant parts used as treatments

(A) Percent use of medicinal plants in various ailments and (B) percent use of vegetative parts of medicinal plants in the study area. $\square$ Leaf, $\square$ fruit, $\square$ bark, $\square$ seed, $\square$ root, $\square$ stem, $\square$ whole plant, $\approx$ flowers, $\square$ others ( $\square$ rhizomes, $\square$ epicarp, $\square$ exudate)

analysis of $P$. juliflora revealed the presence of four piperidine alkaloids with good antibacterial and antifungal activities ${ }^{[16-18]}$.

One of the widely distributed plants from this region is Achyranthes aspera, which has been used by livestock owners and farmers for gastric disturbance (bloat) in animals. This plant is also monographed in Ayurvedic Pharmacopoeia of India. Various pharmacological actions like wound healing ${ }^{[19]}$, spermicidal activity ${ }^{[20]}$ and hepatoprotective activity ${ }^{[21]}$ were reported. Veterinary use of this plant however was not reported.

Butea monosperma is one of the important medicinal plants found throughout India except in arid regions. Ayurvedic Pharmacopoeia of India described the use of stem bark of this plant in chronic diseases like abdominal tumour and other intestinal conditions. But it was surprising to note the use of the plant for instant wound healing purpose, in which stem bark powder was applied to the fresh injury of animals. Though the mechanism of action is still unknown the presence of palastrin, isobutein, and other flavonoids, as well, tannins might help in wound healing through antioxidant and astringent mechanisms ${ }^{[22]}$.
Use of various parts of Azadirachta indica leaves, stem bark in itching and other skin-related diseases have been documented. Triterpenes like nimbin, azadirachtin, limonoid presnet in neem could be responsible for this therapeutic activity ${ }^{[23]}$.

Ricinus communis is one of the important agricultural crops in this area. Participants reported that when animals swallow the seeds of $R$. communis accidentally, a very painful condition resulted. To treat this condition Tamarindus indica was given alone or mixed with palatable food has been reported. $T$. indica is traditionally used as a laxative. Presence of tartaric acid, malic acid, and citric acid, xylose, epicatechin, and phenolics have been reported in this plant ${ }^{[24]}$.

Another interesting finding was the use of Pueraria tuberosa tuber as the galactagogue in milch animals. Tubers of this plant are being used in human ${ }^{[15]}$ but the veterinary use of this plant has not been studied. Some participants cited this Ayurvedic treatment, which was generally practised for the human. Under that, use of Solanum xanthocarpum for respiratory diseases, Terminalia arjuna in hyperventilated oxen, Psoralea corylifolia for the skin and related ailments were also informed ${ }^{[25]}$. All the claims cited were by participants with primary to secondary level education. This shows that Ayurveda system of medicine constituted traditional knowledge that passed from generation to generation since long.

After the thorough survey by interviews with livestock keepers, farmers and traditional healers, it was realized that important ethnoveterinary knowledge is possessed by rural people. This valuable information needs to be validated with in vitro and in vivo studies. Proper utilisation of this information might help in developing alternate therapy of ailments.

\section{Acknowledgements:}

Authors thank all the farmers, owners of cowsheds and animal custodians who shared information enthusiastically.

\section{Conflicts of interest:}

The authors declare that there is no conflict of interests in this paper.

\section{Financial support and sponsorship:}

Nil. 


\section{REFERENCES}

1. Khattak NS, Nouroz F, Inayat Ur Rahman, Noreen S. Ethnoveterinary uses of medicinal plants of district Karak, Pakistan. J Ethnopharmacol 2015; 171:273-9.

2. Bhandari PR, Mukerji B. Role of indigenous drugs in veterinary medicine in India. Indian Vet J 1958;1:55.

3. History of Veterinary Medicine in India [cited 2016 Dec 01]. Available from: http://ecoursesonline.iasri.res.in/mod/ resource/view.php?id=151206.

4. Mazars G. Traditional veterinary medicine in India. Rev Sci Tech 1994;13(2):443-51.

5. gsbb.in/index.php [internet]. Gujarat (India). Gujarat Biodiversity Board 2016 [cited 2016 Dec 02]. Available from: http://www.gsbb.in/gujarat-biodiversity.php.

6. Jadeja BA, Odedra NK, Solanki KM, Baraiya NM. Indigenous animal healthcare practice in district Porbandar, Gujarat. Indian J Tradit Know 2006;5:253-8.

7. World Health Organization. International Union on Conservation of Nature, and World Wide Fund for Nature. Guidelines on the conservation of medicinal plants. Available from: http://apps.who.int/medicinedocs/documents/s7150e/ s7150e.pdf.

8. Ritter AR, Ritter RA, Monteiro MV, Monteiro FO, RodriguesST, Soares ML, et al. Ethnoveterinary knowledge andpractices at Colares Island, Pará state, eastern Amazon, Brazil. J Ethnopharmacol 2012;144:346-52.

9. Piluzza G, Virdis S, Serralutzu F, Bullitta S. Uses of plants,animal and mineral substances in Mediterranean ethnoveterinary practices for the care of small ruminants. J Ethnopharmacol 2015;168:87-99.

10. Shah GL. Flora of Gujarat state, Vallabh Vidhyanagar: Sardar Patel University; 1978.

11. Pade SD, Vyas HB. Aryabhishak athva Hindustanno vaidraj. 19th ed. Bombay: Sastun Sahitya; 1996.

12. Indraji J. Kutchh Svasthanni Vanaspatio. Ahmedabad: Pravin Prakashan; 1998.

13. Pathak AK, Dixit VK. Insecticidal and insect repellent activity of essential oils of $T$. procumbens and Cyathocline lyrata. Fitoterapia 1988;58(3):211-4.

14. Saxena RC, Dixit OP, Sukumaran P. Laboratory assessment of indigenous plant extracts for anti-juvenile hormone activity in Culex quinquefasciatus. Indian J Med Res 1992;95:204-16.

15. Khare CP. Indian Medicinal Plants; an illustrated dictionary. Germany: Springer; 2006.

16. Dos Santos ET, Pereira ML, da Silva CF, Souza-Neta LC, Geris R, Martins D, et al. Antibacterial Activity of the Alkaloid-Enriched Extract from Prosopis juliflora Pods and its Influence on in vitro Ruminal Digestion. Int J Mol Sci 2012; 14:8496-516.

17. Patel HB, Patel UD, Modi CM, Javia BB, Bhatt PR, Pandya KB. In vitro Antimicrobial Effect of Adhatoda vasica, Annona squamosa, Aloe vera, Butea monosperma and Prosopis juliflora. World J Pharm Res 2015;4:1168-77.

18. Ahmed VU, Sultana A, Qazi S. Alkaloids from the leaves of Prosopis juliflora. J Nat Prod 1989;52:497-501.

19. Edwin S, Jarald EE, Deba L, Jaina A, Kingera H, Dutta KR, et al. Wound Healing and Antioxidant Activity of Achyranthes aspera. Pharm Biol 2008;46:824-8.

20. Vasudeva N, Sharma SK. Post-coital antifertility activity of Achyranthes aspera Linn. root. J Ethnopharmacol 2006;107:179-81.

21. Bafna AR, Mishra SH. Effect of methanol extract of Achyranthes aspera Linn. on rifampicin-induced hepatotoxicity in rats. ARS Pharm 2004;45:343-51.

22. Jafri M, Mehta BK. Evaluation of chemical constituents of Butea monosperma (Bark). Int J Pharm Sci Res 2014;5:4548-51.

23. Kumar A, Pareek PK, Kadam VV, Shakyawar DB. Anti-moth activity of Neem (Azadirachta indica A, Juss.) on woollen fabric. Indian J Trad Knowl 2016;15:272-7.

24. Bhadoriya SS, Ganeshpurkar A, Narwaria J, Rai G, Jain AP. Tamarindus indica: Extent of explored potential. Pharmacogn Rev 2011;5:73-81.

25. Pharmacopoeia Commission for Indian Medicine and Homeopathy. 1st ed. Ghaziabad: Ayurvedic Pharmacopoeia of India; 2016. 